\title{
Immunogenic synthetic peptides against my- cobacteria of potential immunodiagnostic and immunoprophylactic value
}

\author{
M E PATARROYO, C A PARRA, C PINILLA, P DEL PORTILLO, \\ M L TORRES, P CLAVIJO, L M SALAZAR \& C JIMENEZ \\ Instituto de Inmunologia, Hospital San Juan de Dios, Universidad \\ Nacional de Colombia, Bogotá, Colombia
}

\section{Introduction}

Tuberculosis continues to be a great public health problem throughout the world. 30.000.000. new cases are reported anually of whom 5.000 .000 die per year.

In search for new immunoprophylactic methods to control this disease, a series of chemical and immunological studies of the Koch's bacilli, capable of inducing a protective immune response against the infection caused by the Mycobacterium tuberculosis have been developed.

The great chemical complexity of this microorganism is seen when analyzing the Mycobacterium tuberculosis sonicates on Coomassie-blue stained SDS-PAGE. A large number of protein bands of different sizes can be observed, with molecular weights ranging from $175 \mathrm{KD}$ (Kilodaltons) to peptides of 6.000 daltons.

Despite the numerous studies on the composition of the $M$. tuberculosis bacilli, little is known about the chemical structure of its proteins mainly due to the fact that only a few have been isolated and characterized in detail.

To understand the biology of $M$. tuberculosis our laboratory started working on the isolation and chemical and immunological characterization of a series of these molecules, centering its interest in the molecules capable of inducing an immunogenic specific response in human beings. This research is the purpose of this report.

\section{Identification of immunogenic molecules of $M$. tuberculosis}

Studies of the specific humoral immune response against the proteins of the M. tuberculosis sonicates developed by the Western blot technique, using sera from more than 400 patients with pulmonary tuberculosis in different stages of development of the disease, show the great antigenic complexity of the Mycobacterium tuberculosis.

When analyzing the reactivity of these sera, according to evolutionary patterns of the disease (Fig. 1), it was found that the individuals in the acute or active stage of tuberculosis presented antibodies against molecules in the range of $80 \mathrm{KD}$ to $50 \mathrm{KD}$ of molecular weight, thus suggesting that these proteins may not play a critical role in the defense against the infection.

When treatment has been started and the patients begin to recover the antibody levels against proteins between $80 \mathrm{KD}$ and $50 \mathrm{KD}$ rise, and the bands become very prominent. Simultaneously, in these sera appear antibodies against another group of proteins of variable 


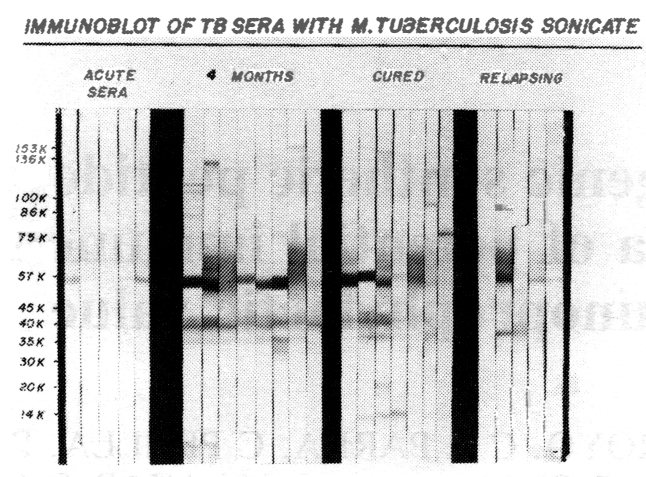

Fig. 1 .

molecular weight, the most prominent being the ones of $43 \mathrm{KD}, 35 \mathrm{KD}$ and $30 \mathrm{KD}$. Antibodies directed against proteins of $153 \mathrm{KD}, 140 \mathrm{KD}, 120 \mathrm{KD}, 115 \mathrm{KD}, 100 \mathrm{KD}$ and $86 \mathrm{KD}$ of molecular weight appear in some individuals in a variable pattern.

When a patient, after a year of treatment, according to all clinical, radiological and laboratory criteria is considered cured, it is found consistently that the antibody levels against proteins of $80 \mathrm{KD}$ to $50 \mathrm{KD}$ continue to be high, as well as those directed against the molecules of $43 \mathrm{KD}, 35 \mathrm{KD}$ and $30 \mathrm{KD}$. In some patients antibodies against molecules of $155 \mathrm{KD}$, $140 \mathrm{KD}, 100 \mathrm{KD}$ and $86 \mathrm{KD}$ are found without a consistent pattern.

Systematically, in a peculiar way, the sera of these cured patients show a high level of antibodies against the 13KD molecule.

The analysis of sera of some relapsing patients showed that antibodies against the molecules of $80 \mathrm{KD}$ to $50 \mathrm{KD}$ decrease considerably and that the antibodies against the proteins of $43 \mathrm{KD}, 33 \mathrm{KD}$ and $13 \mathrm{KD}$ totally disappear, while circumstantially showing in some patients antibodies against proteins of $155 \mathrm{KD}, 140 \mathrm{KD}, 120 \mathrm{KD}, 110 \mathrm{KD}, 86 \mathrm{KD}$ and $35 \mathrm{KD}$.

The disappearance of the antibodies directed against the molecules of $43 \mathrm{KD}, 33 \mathrm{KD}$ and $130 \mathrm{KD}$ during relapse, suggest that antibodies against these proteins can be directly involved in the control process of the disease since they are apparent in recovering and cured patients but not in the relapses or the acute stages of the disease.

The search for these molecules in other mycobacterial sonicates by the Western blot technique, studied with the same tuberculosis patients' sera, showed that the proteins of $43 \mathrm{KD}$, $33 \mathrm{KD}$ and $13 \mathrm{KD}$ identified in sonicates of the M. tuberculosis are not found in sonicates of BCG, Pasteur sub-strain (Fig. 2). The molecules of 144KD, $110 \mathrm{KD}, 86 \mathrm{KD}$ and 68KD are not found in the BCG, Pasteur sub-strain strongly suggesting that these molecules are selectively found or at least in a higher concentration level in Mycobacterium tuberculosis.

\section{Immunologic studies of some $M$. tuberculosis isolated proteins}

Based on this data the isolation of these proteins was carried out by different methods, obtaining milligram quantities of molecules of $13 \mathrm{KD}, 30 \mathrm{KD}, 33 \mathrm{KD}, 43 \mathrm{KD}, 50 \mathrm{KD}, 60 \mathrm{KD}$, $67 \mathrm{KD}, 78 \mathrm{KD}, 86 \mathrm{KD}$ and $175 \mathrm{KD}$ against which antisera in rabbits were produced.

The exchange of reagents with Dr. M. Harboe from the University of Oslo, showed that some of these antisera had not been only recognizing molecules previously identified in the BCG reference system, but also that some molecules present in the Mycobacterium tuberculosis sonicates, had not been identified in the BCG reference system. 


\section{IMMUNOBLOT OF M.TUBERCULOSIS AND BCG WITH PATIENTS SERA}

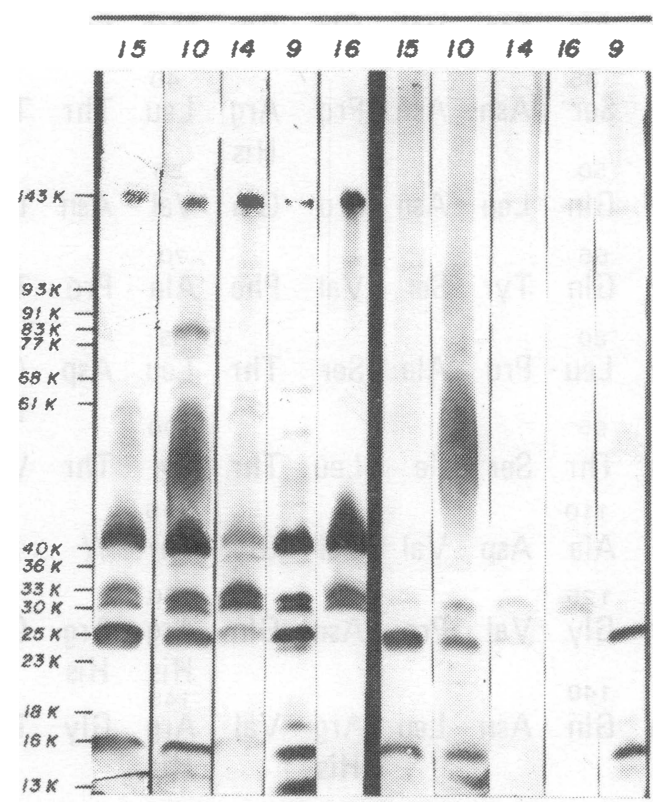

Fig. 2.

The molecule of $175 \mathrm{KD}$ corresponds to either the Beta antigen, $M$. leprae antigen or BCG-51; the protein 50KD corresponds to BCG-20; the molecule of $47 \mathrm{KD}$ is immunologically similar to the BCG-63; the molecule of $43 \mathrm{KD}$ present in high concentrations of $\mathrm{Myco}$ bacterium tuberculosis was not detected in the reference system of BCG the same as the molecules $86 \mathrm{KD}, 33 \mathrm{KD}$ and $13 \mathrm{KD}$.

These data are in agreement with the information obtained from the patients' sera where the proteins $86 \mathrm{KD}, 43 \mathrm{KD}, 33 \mathrm{KD}$ and $13 \mathrm{KD}$ of molecular weight, selectively recognized by the patients' sera as molecules present in high concentrations in the Mycobacterium tuberculosis sonicates were not found in the BCG Pasteur sub-strain sonicates.

\section{Immunochemical studies of mycobacterial proteins}

As a result of the collaborative study with Harboe's group, we received from them a series of identified and isolated proteins denominated MPB-70, MPB-80, MPT-59 and MPB-64 from which our group determined the amino acid sequences.

The complete amino acid sequence of MPB-70 was determined (Table 1), and it was found identical in the first $35 \mathrm{~N}$ terminal residues to the MPB-80. The $\mathrm{N}$ terminal amino acid sequences of the MPB-64, MPB-59 and MPT-59 molecules were also identified (Table 2).

The partial amino acid sequence from the molecules of $13 \mathrm{KD}, 33 \mathrm{KD}, 35 \mathrm{KD}, 40 \mathrm{KD}$, $68 \mathrm{KD}, 77 \mathrm{KD}$ and $86 \mathrm{KD}$ were also obtained from the isolated proteins of $M$. tuberculosis (Table 3). 


\begin{tabular}{|c|c|c|c|c|c|c|c|c|c|c|c|c|c|c|}
\hline Gly & Asp & Leu & Val & $\begin{array}{c}5 \\
\text { Gly }\end{array}$ & Pro & Gly & Val & Ala & $\begin{array}{l}10 \\
\text { Glu }\end{array}$ & Tyr & Ala & Ala & Ala & $\begin{array}{c}15 \\
\text { Asn }\end{array}$ \\
\hline Pro & Thr & Gly & Glu & $\begin{array}{r}20 \\
\text { Ala }\end{array}$ & Ser & Val & Gln & Gly & $\begin{array}{c}25 \\
\text { Met }\end{array}$ & Ser & $\mathrm{G} \ln$ & Asp & Pro & $\begin{array}{r}30 \\
\text { Val }\end{array}$ \\
\hline Ala & Val & Ala & Ala & Ser & Asn & Asn & Pro & $\begin{array}{l}\text { Arg } \\
\text { His }\end{array}$ & Leu & Thr & Thr & Leu & Thr & $\begin{array}{r}45 \\
\text { Ala }\end{array}$ \\
\hline Ala & Leu & Ser & Gly & $\begin{array}{l}50 \\
\text { Gln }\end{array}$ & Leu & Asn & Pro & $\mathrm{G} \ln$ & $\begin{array}{r}55 \\
\text { Val }\end{array}$ & Asn & Leu & Val & Asn & $\begin{array}{l}60 \\
\text { Thr }\end{array}$ \\
\hline Leu & Asn & $\mathrm{His}$ & Gly & $\begin{array}{l}65 \\
\text { Gln }\end{array}$ & Tyr & Ser & Val & Phe & $\begin{array}{c}70 \\
\text { Ala }\end{array}$ & Pro & Thr & Asn & Ala & $\begin{array}{c}75 \\
\text { Ala }\end{array}$ \\
\hline Phe & Ser & Ser & Lys & $\begin{array}{l}80 \\
\text { Leu } \\
95\end{array}$ & Pro & Ala & Ser & Thr & $\begin{array}{c}85 \\
\text { Leu } \\
100\end{array}$ & Asp & $\begin{array}{l}\text { Arg } \\
\mathrm{His}\end{array}$ & Leu & Thr & $\begin{array}{c}90 \\
\text { Asn } \\
105\end{array}$ \\
\hline Ser & Ser & Leu & Leu & Thr & Ser & Ile & Leu & Thr & Tyr & Thr & Val & Val & Ala & Gly \\
\hline GIn & Thr & Ser & Pro & $\begin{array}{l}110 \\
\text { Ala }\end{array}$ & Asp & Val & Val & Gly & $\begin{array}{l}115 \\
\text { Thr }\end{array}$ & /I & /I & Val & Ile & $\begin{array}{l}120 \\
\text { Gly }\end{array}$ \\
\hline $\begin{array}{l}\text { Arg } \\
\text { His }\end{array}$ & $\begin{array}{l}\text { Arg } \\
\text { His }\end{array}$ & Pro & Gly & $\begin{array}{l}125 \\
\text { Gly }\end{array}$ & Val & Pro & Asn & Gln & $\begin{array}{l}130 \\
\text { Arg } \\
\text { His } \\
145\end{array}$ & $\begin{array}{l}\text { Arg } \\
\mathrm{H} \text { is }\end{array}$ & Gly & Asp & /I & $\begin{array}{l}135 \\
/ /\end{array}$ \\
\hline Lys & Gly & Val & Asn & $\mathrm{G} \ln$ & Asn & Leu & $\begin{array}{l}\text { Arg } \\
\text { His }\end{array}$ & Val & $\begin{array}{l}\text { Arg } \\
\mathrm{His}\end{array}$ & Gly & Tyr & Pro & Gly & $\begin{array}{l}\text { Arg } \\
\text { His }\end{array}$ \\
\hline
\end{tabular}

Table 1. Amino acid sequence of MPB 70

\section{Immunogenic synthetic peptides against mycobacteria}

Based on these amino acid sequences and trying to identify epitopes of potential immunogenic value against Mycobacterium tuberculosis the chemical synthesis of a series of these peptides corresponding to amphilicity or alphahydrophilic areas of these molecules was carried out, obtaining them in a pure form according to their HPLC chromatograms (Table 4).

The antigenicity study of the synthetized peptides corresponding to an amphilitic area of the 13KD molecule showed that this peptide reacted in the Dot-Blot test, with sera of patients who had recovered from tuberculosis but not with sera of patients in the acute stages of the disease, similar to what happens with the complete protein. These data strongly suggest that this epitope can be involved in the protective immune response against Mycobacterium tuberculosis.

Studies on delayed type hypersensitivity (DTH) reactions showed the existence of specific reactivities against the synthetic peptides: the sythetic peptide of the 13KD molecule induced a selective DTH response to Mycobacterium tuberculosis not observed when the guinea pigs were immunized with other mycobacterial sonicates or lysates. Similar circumstances happened with the peptide corresponding to the MPT-64 molecule where no delayed hypersensitivity was observed in animals immunized with mycobacteria different from $\mathrm{Myco}$ bacterium tuberculosis. These data are in concordance with the selective expression of this protein in the Koch bacilli (Table 5).

Histopathology studies showed on the peptide innoculation site a classical delayed type hypersensitivity response with a marked infiltration of lymphoid and monocytic as well as 
MPB-70 Gly Asp Leu Val Gly Pro Gly Val Ala Glu Tyr Ala Ala Ala Asn 18 KD Pro Thr Gly Glu Ala Ser Val Gln Gly Met Ser Gln Asp Pro Val

MPB-80 Gly Asp Leu Val Gly Pro Gly Val Ala Glu Tyr Ala Ala Ala Asn 18 KD Pro Thr Gly Glu Ala Ser Val Gln Gly Met Ser Gln Asp Pro Val

MPB-59 Phe Ser Arg Pro Gly Leu Pro Val Glu Tyr Leu Gin Val Pro Ser His

$30 \mathrm{KD}$ Pro Ser Met Gly Gly Cys lle Lys Val Gln Phe Gln Ser Gly Gly

MPB-64 Ala Pro Lys Thr Tyr Arg Glu Glu Leu Lys Gly Thr Asp Thr Gly His

23 KD Gln Ala Tyr Gln lle Gln Met Ser Asp Pro Ala Tyr Asn lle Asn

Table 2. N-terminals of some BCG isolated proteins

MTP-13 Ala Lys Val Asn Ile Lys Pro Glu Arg Asp Lys Ile Leu Val Gln $13 \mathrm{KD}$ Arg Asn Glu Ala Arg Val Glu Ala Glu Glu Glu Val Ala Ala Ala His

MTP-59 Phe Ser Arg Pro Gly Leu Pro Val Glu Tyr Leu Gln Val Pro Ser 30 KD Pro Ser Met Gly Gly Cys Ile Lys Val GIn Phe Gln Ser Gly Gly MTP-33 Trp Ser Ser Leu Glu Glu Gly Thr Leu Thr Thr Arg Ala Tyr Glu 33 KD Leu Arg Gly Glu His

MTP.35 Trp Val Glu Val Arg Gln Val Trp Val Trp Arg Leu Arg Trp Arg 35 KD Arg Thr Glu Leu Asn Trp Leu Val Arp Arg Leu Arg Arg Ser Leu $\mathrm{His} \quad \mathrm{His} \mathrm{His} \mathrm{His}$

MTP.43 Ser Pro Trp lle Leu Lys Gly Lys Ala Lys

$43 \mathrm{KD}$

MTP.68 Trp Met Thr Met Thr - - - Cys - - Cys

$68 \mathrm{KD}$

MTP-77 Gly Lys Arg lle Ala Tyr Asp Arg Glu Ala Ala Ala Ala Ala Leu His

$77 \mathrm{KD} \quad$ Leu Leu Leu

Table 3. N-terminals of some M. tuberculosis isolated proteins 
some plasma cells. This demonstrates that the synthetic peptides corresponding to a molecular sequence of amono acids pertaining selectively to $M$. tuberculosis or other mycobacteria can be used in a near future as potentially useful reagents for immunodiagnosis since they permit the detection of antibodies or specific immunologic cellular response for each of the mycobacteria under study.

\section{Acknowledgements}

This work was supported by grants from the Ministerio de Salud Pública de Colombia and the German Leprosy Relief Association and Nederlandse Stichting voor Leprabestrijding (ILEP grant 66.30.03.78.00).

\begin{tabular}{|c|c|c|c|c|c|c|c|c|c|c|c|c|c|c|c|c|c|c|}
\hline \multirow[t]{2}{*}{ Peptide Nr. } & \multirow[t]{2}{*}{ Molecule } & \multirow[t]{2}{*}{ Residues } & \multicolumn{16}{|c|}{ Sequence } \\
\hline & & & 1 & 2 & 3 & 4 & 5 & 6 & 7 & 8 & 9 & 10 & 11 & 12 & 13 & 14 & 15 & 16 \\
\hline SM 8 & MTP 13 & $1 \cdot 9$ & Ala & Lys & Val & Gin & Ile & Lys & Pro & Glu & Arg & & & & & & & \\
\hline SM 9 & MPB 70 & $19-28$ & Glu & Ala & His & Val & Glu & Ala & Glu & Glu & $\mathrm{His}$ & Val & & & & & & \\
\hline SM 14 & MPB 64 & 1.16 & Ala & Pro & Leu & Thr & Tyr & Arg & Glu & Glu & Leu & Lys & Gly & Gly & Asp & Thr & Gly & Gin \\
\hline SM 15 & MPB 59 & $19-30$ & Gly & Gly & Cys & Ile & Lys & Val & Gln & Phe & $\mathrm{G} \ln$ & $\mathrm{His}$ & Gly & Gly & & & & \\
\hline SM 67 & MTP 33 & 1.12 & Trp & Ser & Ser & Leu & Glu & Glu & Gly & Thr & Leu & Thr & Thr & Arg & & & & \\
\hline SM 68 & MTP 35 & $10-24$ & Trp & $\operatorname{Arg}$ & Leu & Arg & Trp & Arg & Arg & Thr & Glu & Leu & Asn & Trp & Leu & Val & Arg & \\
\hline SM 69 & MTP 40 & 1.10 & Ser & Pro & Trp & Ile & Leu & Lys & Gly & Lys & Ala & Lys & & & & & & \\
\hline SM 70 & MTP 35 & 25.37 & Arg & leu & $\operatorname{Arg}$ & Arg & Ser & Leu & Leu & Leu & $\operatorname{Arg}$ & Arg & Thr & Trp & $\operatorname{Trp}$ & & & \\
\hline SM 71 & MTP 33 & 7.19 & Gly & Thr & Leu & Thr & Thr & Arg & Ala & Tyr & Glu & Leu & Arg & Gly & Glu & & & \\
\hline SM 72 & MTP 13 & 8.22 & Leu & Arg & Asp & Lys & Ile & Leu & Val & Gln & Arg & Asn & Glu & Ala & Arg & Val & & \\
\hline
\end{tabular}

Table 4. Peptides synthetized for DTH studies

$\begin{array}{lcccc}\text { Micrograms } & \begin{array}{c}\text { M. tub. } \\ \text { H37 Rv } \\ \text { in 0.1 } \mathbf{~} \mathbf{l}\end{array} & \begin{array}{c}\text { BCG } \\ \text { Pasteur } \\ \mathbf{n = 5}\end{array} & \begin{array}{c}\text { M. kansasii } \\ \mathbf{n}=\mathbf{5}\end{array} \\ \text { SM 8 } & 50 & 4 \pm 1 & 0 & 0 \\ \text { MTP 13 K } & 100 & 6 \pm 3 & 0 & 0 \\ & 250 & 7 \pm 3 & 0 & 0 \\ \text { SM 9 } & 50 & 0 & 0 & 0 \\ \text { MPB 70 K } & 100 & 0 & 0 & 0 \\ & 250 & 0 & 0 & 0 \\ \text { SM 14 } & 50 & 0 & 0 & 0 \\ \text { MPB 64 K } & 100 & 0 & 0 & 2.5 \pm 3 \\ & 250 & 6 \pm 4 & 3 & 4 \pm 3 \\ \text { SM 15 } & 50 & 3 \pm 2 & 0 & 0 \\ \text { MPB 59 K } & 100 & 7 \pm 3 & 0 & 2 \\ & 250 & 10 \pm 3 & 0 & 5.1 \pm 2\end{array}$

Table 5. DTH of some synthetic peptides 